\title{
PENERAPAN MODEL PEMBELAJARAN KOOPERATIF TIPE TEAM ASSISTED INDIVIDUALIZATION (T.A.I) DALAM PEMBELAJARAN KOMPETENSI DASAR MENDESKRIPSIKAN RANGKAIAN LOGIKA DASAR
}

\author{
Irma Agustina Manalu dan Marsangkap Silitonga \\ Alumni Jurusan Pendidikan Teknik Elektro FT Unimed \\ Dosen Jurusan Pendidikan Teknik Elektro FT Unimed
}

\begin{abstract}
ABSTRAK
Penelitian ini bertujuan untuk mengetahui perbedaan hasil belajar mendeskripsikan rangkaian logika dasar antara siswa yang diajar dengan model pembelajaran kooperatif tipe team assisted individualization (TAI), dengan siswa yang diajar menggunakan model pembelajaran konvensional. Penelitian dilakukan pada siswa kelas X program keahlian Teknik Instalasi Tenaga Listrik di SMK Negeri 2 Medan tahun pelajaran 2015/2016. Populasi penelitian sebanyak lima kelas dan diambil dua kelas sebagai sampel yaitu kelas $\mathrm{X}_{1}$ dan $\mathrm{X}_{2}$ masingmasing sebanyak 29 siswa. Metode penelitian adalah eksperimen dengan rancangan "Randomized Control Group Posttest Only Design". Data penelitian dijaring dengan tes menggunakan instrument berbentuk tes objektif pilihan berganda. Instrumen tes digunakan setelah melalui ujicoba untuk mengetahui validitasnya dan reliabilitasnya. Setelah melalui ujicoba diperoleh sebanyak 25 butir tes yang valid dengan koefisien reliabilitas sebesar 0,625. Hipotesis penelitian diuji dengan analisis statistik uji-t, yang digunakan setelah memenuhi uji persyaratan analisis yaitu uji normalitas dan uji homogenitas.Hasil belajar mendeskripsikan rangkaian logika dasar siswa yang diajar dengan model kooperatif tipe TAI memiliki nilai rata-rata 89,6 sedangkan siswa yang diajar dengan model pembelajaran konvensional memiliki nilai rata-rata 79,1. Dengan menggunakan analisis statistik uji-t disimpulkan bahwa hasil belajar siswa yang diajar dengan model pembelajaran kooperatif tipe team assisted individualization (TAI) lebih tinggi dibandingkan dengan siswa yang diajar dengan menggunakan model konvensional.
\end{abstract}

\section{Kata Kunci : Model Pembelajaran, Team Assisted Individualization (TAI), Rangkaian logika dasar}

\section{PENDAHULUAN}

Sekolah Menengah Kejuruan (SMK) bertujuan mempersiapkan siswa memasuki dunia kerja, dan juga mempersiapkan siswa untuk melanjutkan pendidikan ke tingkat yang lebih tinggi. Pembelajaran di SMK dilaksakan bukan hanya di sekolah, melainkan juga di industri yang dikenal dengan PSG (Pendidikan Sistem Ganda) SMK melaksanakan proses belajar mengajar, baik belajar di kelas maupun di luar kelas, secara teori maupun praktek.

Belajar merupakan suatu proses perubahan perilaku berdasarkan pengalaman dan latihan. Kegiatan belajar dilakukan untuk mencapai tujuan yang telah dirumuskan. Tujuan pembelajaran dapat tercapai bila kegiatan tersebut terlaksana dengan baik. Interaksi yang baik antara guru dan siswa tercipta jika kedua pihak saling menerima dan menyadari tujuan mereka.

Model pembelajaran merupakan kerangka kerja yang terstruktur yang juga dapat sebagai pemandu untuk mengembangkan lingkungan dan aktivitas belajar yang kondusif. Dengan model yang baik dan tepat siswa akan mendapatkan hasil belajar yang baik. Model pembelajara yang digunakan di sekolah pada umumnya adalah model konvensional. Model ini merupakan model pembelajaran yang berpusat pada guru. Masalah utama dalam penggunaan model ini adalah terjadinya komunikasi satu arah yang mengakibatkan siswa bersikap 
pasif dan hanya menunggu informasi dari penyampaian guru. Kondisi yang demikian mengakibatkan hasil belajar siswa belum mencapai kriteria yang diinginkan.

Perlu dilakukan perbaikan pada proses belajar mengajar untuk mencapai tujuan dengan hasil belajar yang lebih baik. Perbaikan yang dimaksud bisa dilakukan melalui model pembelajaran. Perlu usaha untuk mengadaptasikan pembelajaran dengan perbedaan individual siswa yang memungkinkan keterlibatan siswa untuk bekerja dengan siswa-siswa lain yang berbeda secara akademik sehingga tercipta sikap positif di antara mereka. Model pembelajaran kooperatif tipe Team Assisted Individualization (TAI) bisa menjadi sesuatu yang sesuai dengan kebutuhan siswa. Ini merupakan model pembelajaran berkelompok yang menuntut keaktifan setiap individu yang memiliki kemampuan heterogen. Setiap individu dengan tingkat kemampuan yang berbeda akan saling membantu dalam menyelesaikan permasalahan dalam kelompoknya. Siswa yang memiliki kemampuan tinggi memiliki kesempatan untuk ikut terlibat membantu siswa yang memiliki kemampuan rendah, demikian sebaliknya.

Pembelajaran rangkaian logika yang mengkaji permasalahan terkait dengan gerbang-gerbang logika mulai dari gerbang AND, OR, NOT, NAND, NOR, XOR dan XNOR, membutuhkan keaktifan dan kerjasama di antara sesama siswa. Untuk itu diperlukan model pembelajaran yang memungkinkan para siswa untuk berperan secara aktif dalam pembelajaran. Penelitian ini dilakukan untuk melihat pengaruh penggunaan model pembelajaran kooperatif type Team Assisted Individualization (TAI) terhadap hasil belajar gerbang logika dasar. Pengaruh tersebut akan dilihat dari perbedaan hasil belajar antara siswa yang diajar dengan model kooperatif type TAI dengan siswa yang diajar dengan model pembelajaran konvensional. Dengan demikian yang menjadi rumusan masalah atau pertanyaan penelitian aialah, apakah hasil belajar mendeskripsikan rangkaian logika dasar pada siswa yang diajar dengan dengan model kooperatif tipe TAI lebih baik dibandingkan dengan siswa yang diajar dengan model pembelajaran konvensional? Dengan demikian tujuan penelitian ialah untuk mengetahui apakah hasil belajar mendeskripsikan rangkaian logika dasar pada siswa yang diajar model pembelajaran kooperatif type TAI lebih baik dibandingkan dengan siswa yang diajar dengan model pembelajaran konvensional. Hasil penelitian ini diharapkan bermanfaat untuk memberikan wawasan baru bagi guru tentang penerapan dari model pembelajaran kooperatif tipe TAI dalam proses pembelajaran.

\section{KAJIAN TEORITIS}

Belajar adalah suatu proses perubahan tingkah laku. Seseorang dikatakan belajar jika ia mampu menunjukkan perubahan perilaku sebagai hasil dari pengalaman (Gagne dalam Ratna, 2011:2). Tujuan utama belajar adalah bahwa apa yang dipelajari itu berguna di kemudian hari, yaitu membantu kita untuk dapat belajar terus dengan cara yang lebih muda, karena pada dasarnya sepanjang hidup manusia adalah belajar. Menurut Bruner yang dikutip Nasution (1982: 9), proses belajar dibedakan menjadi 3 (tiga ) fase yaitu:

1. Informasi. Dalam belajar, siswa akan memperoleh informasi. Informasi dapat berupa informasi yang menambah pengetahuan yang kita miliki, ada yang memperdalamnya, bahkan ada informasi yang bertentangan dengan apa yang telah kita pahami sebelumnya

2. Transformasi. Informasi harus dianalisis, diubah atau ditransformasikan menjadi lebih terkonsep agar dapat digunakan pada hal-hal yang lebih luas.

3. Evaluasi. Menilai sampai di manakah kita memperoleh pengetahuan dan tranformasi itu dapat digunakan.

Hasil belajar merupakan nilai dari kemampuan yang dimiliki seorang siswa setelah ia menerima perlakukan dari pengajar (guru). Hasil belajar dapat dilihat atau diukur melalui evaluasi tingkat keberhasilan belajar berupa tes. Dalam evaluasi ini, kemampuan siswa dalam hal penguasaan materi dapat dilihat untuk menentukan kedudukannya dalam kelompok atau kelasnya. Hasil belajar dapat dipengaruhi oleh berbagai hal. Secara 
umum Hasil belajar dipengaruhi dua, yaitu : (1) Faktor internal (factor dalam diri) dimana hasil belajar yang baik, dapat diperoleh jika secara fisiologis siswa memiliki kebugaran tubuh dan kondisi panca indera yang baik. selain itu, secara psikologis yang berupa sikap, bakat, minat, motivasi dan kepribadian; (2) Faktor eksternal (factor diluar diri), yaitu teman, guru, keluarga, masyarakat, kondisi lingkungan rumah, sekolah.

Taksonomi Bloom membagi hasil belajar atas tiga ranah, yaitu kognitif, afektif dan psikomotorik. Ranah kognitif merupakan kemampuan berfikir yang terdiri atas enam jenjang yaitu pengetahuan $(\mathrm{C} 1)$, pemahaman (C2), aplikasi (C3), analisis (C4), sintesis (C5), dan evaluasi (C6). Ranah Afektif berupa minat, perhatian, sikap, emosi, penghargaan dan pembentukan karakteristik diri yang terdiri atas jenjang 1) penerimaan, 2) penanggapan, 3) penghargaan, 4) pengorganisasian, 5) penjatidirian. Ranah psikomotorik merupakan kemampuan gerak yang bukan merupakan bagian biologis tetapi oleh kematangan psikologis. Jadi, kemampuan ini merupakan kemampuan yang dapat dipelajari. Berdasarkan penjelasan di atas, hasil belajar merupakan perubahan peserta didik yang mengikuti kegiatan belajar sesuai dengan tujuan pembelajaran yang telah ditentukan. Hasil belajar tersebut akan menentukan tingkat kemampuan penguasaan seseorang terhadap materi pelajaran yang disampaikan dalam proses belajar.

Mendeskripsikan rangkaian logika dasar adalah satu kompetensi dasar dalam pelajaran dasar dan pengukuran listrik yang merupakan salah satu mata pelajaran sekolah menengah kejuruan program teknik instalasi tenaga listrik (TITL). Mendeskripsikan merupakan kemampuan memahami, menganalisis pengetahuan faktual, konseptual, dan prosedural berdasarkan rasa ingin tahunya tentang ilmu pengetahuan, teknologi, seni, budaya, dan humaniora. Siswa perlu mempelajari dasar dan pengukuran listrik untuk mengetahui dan atau menambah pengetahuan dalam hal pengukuran listrik. Mendeskripsikan rangkaian logika dasar mencakup berbagai rangkaian logika yang terdiri atas gerbang
AND, OR, NOT, NAND, NOR, XOR dan XNOR.

Hasil belajar mendeskripsikan rangkaian logika dasar adalah kemampuan memahami hingga meternganalisis rangkaian logika dasar setelah mengikuti pembelajaran dasar dan pengukuran listrik. Hasil belajar dalam penelitian ini adalah hasil belajar pada kompetensi dasar mendeskripsikan rangkaian logika dasar. Hasil belajar dibandingkan antara siswa yang diajar dengan model pembelajaran kooperatif type TAI dengan siswa yang diajar dengan model pembelajaran konvensional.

Model pembelajaran adalah kerangka konseptual yang melukiskan prosedur yang sistematis dalam mengorganisasikan pengalaman belajar untuk mencapai tujuan belajar tertentu (Soekamto dalam Shoimin, 2014: 23). Model pembelajaran akan memberi arah dan bentuk dari pembelajaran yang akan dilakukan terhadap siswa. Lebih lanjut Shoimin mengutip pendapat Kardi dan Nur mengemukakan model pembelajaran memiliki empat ciri khusus, yaitu : 1) rasional yang disusun oleh para pencipta dan pengembangnya, 2) landasan pemikiran tentang apa dan bagaimana siswa belajar, 3) tingkah laku mengajar yang diperlukan agar model tersebut dapat dilaksanakan dengan berhasil, 4) lingkungan belajar yang diperlukan agar tujuan belajar dapat tercapai.Model pembelajaran akan memudahkan guru dan siswa dalam kegiatan belajar mengajar. Kegiatan guru dan siswa akan lebih terarah dalam mencapai tujuan pembelajaran. Penerapan kurikulum tahun 2013 mengarahkan siswa untuk aktif dalam kegiatan belajar sehingga perlu yang menuntut siswa untuk aktif dan bertanggung jawab dalam kegiatan belajar.

Model pembelajaran kooperatif adalah salah satu model interaksi sosial yang menekankan relasi individu dengan orang lain (Huda, 2013:109). Sasaran utamanya adalah membantu siswa untuk belajar bekerja sama, mengidentifikasi dan menyelesaikan masalah, baik secara akademik maupun sosial. Pembelajaran kooperatif merujuk pada berbagai macam model pembelajaran dimana siswa bekerja dalam kelompok-kelompok kecil untuk saling membantu satu sama lain 
dalam mempelajari materi pembelajaran. Salah satu asumsi yang mendasari pengembangan model kooperatif ini adalah bahwa sinergi yang muncul melalui kerja sama akan meningkatkan motivasi yang jauh lebih besar dari pada dalam lingkungan kompetisi individual. Para siswa akan duduk bersama dalam kelompok yang beranggotakan siswa berkemampuan heterogen, biasanya empat hingga enam orang.

Model pembelajaran kooperatif tipe team assisted individualization (TAI) merupakan sebuah program pedagogik yang berusaha mengadaptasikan pembelajaran dengan perbedaan individual siswa secara akademik (Robert Slavin dalam Huda, 2013:200), Tujuan TAI adalah meminimalisasi pembelajaran individual, serta untuk meningkatkan pengetahuan, kemampuan serta motivasi siswa dengan belajar kelompok. Sintaks model kooperatif type TAI terdiri atas: 1) Memberikan tes awal atau melihat nilai rata-rata siswa pada bab sebelumnya; 2) Siswa dibagi menjadi tim yang terdiri dari 4-5 orang yang bersifat heterogen; 3) Guru memberikan materi secara singkat sebelum pemberian tugas kelompok; 4) Guru menekankan persepsi kepada siswa bahwa keberhasilan setiap siswa ditentukan oleh keberhasilan kelompoknya dan sebaliknya; 5) Siswa melakukan belajar kelompok bersama rekan satu timnya untuk mengerjakan tugas kelompok yang diberikan guru. Dalam hal ini guru tetap memberikan bimbingan individual bagi siswa yang membutuhkan dan setiap siswa sebagai anggota kelompok juga menjadi peer tutoring (tutor sebaya).

1) Hasil kerja kelompok diskor di akhir pengajaran dan tim super akan mendapakan penghargaan dari guru.

2) Guru memberi kembali pengajaran kepada setiap kelompok tentang materi yang sudah didiskusikan.

3) Guru meminta siswa untuk mengerjakan tes-tes yang membuktikan kemampuan mereka yang sebenarnya.

Pembelajaran kompetensi mendeskripsikan gerbang logika dasar dengan model TAI dilakukan dengan memberikan masalah kepada setiap kelompok. Masing-masing kelompok membagikan soal/masalah untuk dipertanggungjawabkan oleh masing-masing anggota secara individu. Masalah yang dimunculkan adalah terkait sistem bilangan dan rangkaian logika AND, OR, NOT, NAND, NOR, XOR, XNOR. Soal yang sudah dibahas oleh anggota secara individu kemudian dibawakan ke dalam kelompok untuk didiskusikan kebenaran dan atau kesalahan dalam penyelesaian masalah.

Model konvensional dalam hal ini merupakan model pembelajaran yang biasa digunakan guru di sekolah. Guru menjadi pusat yang menyampaikan informasi yang berkaitan dengan kompetensi dasar. Informasi diberikan secara langsung dengan maksud agar siswa menguasai materi pelajaran secara optimal. Pembelajaran dilakukan dengan ceramah, diikuti dengan tanya jawab dan adanya pemberian tugas. Biasanya materi pelajaran yang disampaikan adalah materi yang sudah jadi. Dalam model ini, siswa dituntut untuk menghafal materi yang telah disampaikan. Model konvensional adalah model pembelajaran tradisional atau disebut juga dengan model ceramah, karena sejak dulu model ini telah dipergunakan sebagai alat komunikasi lisan antara guru dengan siswa dalam proses belajar dan pembelajaran (Djamarah, 2016). Pembelajaran konvensional ditandai dengan ceramah yang diiringi dengan penjelasan, serta pembagian tugas dan latihan.

Hasil belajar akan ditentukan oleh banyak hal, baik dari dalam maupun dari luar diri siswa. Penggunaan model pembelajaran yang menuntut aktivitas dan kreativitas siswa akan sangat mendukung proses belajar siswa. Model pembelajaran TAI diterapkan dengan pembentukan kelompok di mana masingmasing anggota memiliki tanggung jawab yang sama terhadap keberhasilan kelompoknya. Jika dibandingkan dengan model pembelajaran konvensional, model pembelajaran TAI akan lebih menarik dan menyenangkan, yang pada akhirnya akan meningkatkan hasil belajar siswa. Model konvensional berpusat kepada guru dimana guru adalah pemberi informasi secara langsung. Model yang demikian merupakan komunikasi satu arah. Berdasarkan uraian 
tersebut diduga bahwa penggunaan model pembelajaran kooperatif type TAI akan memberikan hasil yang lebih baik bila dibandingkan dengan hasil belajar yang menggunakan model pembelajaran konvensional. Atas dasar pemikiran tersebut, ditetapkan hipotesis penelitian yaitu "hasil belajar siswa pada kompetensi dasar mendeskripsikan rangkaian logika dasar yang diajar dengan menggunakan model pembelajaran kooperatif tipe TAI lebih tinggi dari hasil belajar siswa dengan menggunakan model pembelajaran konvensional.

\section{METODOLOGI PENELITIAN}

Penelitian ini adalah eksperimen dengan rancangan "Randomized Control Group Posttest Only Design" (Isaac dan Michael, 1982: 69). Penelitian dilaksanakan di SMK Negeri 2 Medan. Populasi adalah siswa kelas $\mathrm{X}$ program kejuruan teknik instalasi tenaga listrik pada tahun pelajaran 2015/2016 yang terdiri atas lima kelas. Hasil penentuan sampel secara acak mendapatkan dua kelas sampel yaitu kelas $\mathrm{X}_{1}$ dan kelas $\mathrm{X}_{5}$. Selanjutnya hasil pengundian menetapkan kelas $\mathrm{X}_{1}$ sebagai kelas eksperimen dengan model pembelajaran kooperatif type TAI sedangkan kelas $\mathrm{X}_{5}$ sebagai kelas kontrol dengan model pembelajaran konvensional.

Untuk rancangan penelitian diadakan pengontrolan validitas yaitu: Validitas internal meliputi pengontrolan pengaruh historis, pengaruh kematangan, pengaruh instrumen pengukuran, pengaruh kehilangan dan pengaruh kontaminasi antar kelompok; serta Validitas eksternal meliputi validitas populasi dan validitas instrumen pengukuran. Variable penelitian terdiri atas vriabel bebas yaitu model pembelajaran yang terdiri atas model kooperatif tipe Team Assisted Individualization (TAI) dan model konvensional. Variabel terikat adalah hasil belajar mendeskripsikan rangkaian logika dasar dalam mata pelajaran dasar dan pengukuran listrik.

Data dikumpulkan dengan tes pada akhir proses pembelajaran. Instumen tes berbentuk tes objektif pilihan ganda 5 pilihan dengan skor 1 (satu) untuk jawaban benar dan skor 0 (nol) untuk jawaban salah/tidak menjawab. Instrumen disusun mewakili semua materi yng disampaikan selama eksperimen. Sebelum digunakan, instrument terlebih dahulu diujicoba untuk mengetahui validitas (kesahihan) dan reliabilitas (keterandalan) instrument tersebut. Dari hasil ujicoba diperoleh sebanyak 25 butir tes yang valid. Selanjutnya dengan menggunakan rumus Kuder Richardson (KR-20) diperoleh reliabilitas tes yang valid sebesar 0,625 (kategori tinggi). Data penelitian dianalisis dengan statistik dekriptif untuk deskripsi hasil penelitian, serta statistik inferensial Ujit untuk menguji hipotesis, setelah dipenuhi uji persyaratan analisis yaitu uji normalitas dengan Uji Liliefors dan uji homogenitas dengan uji $\mathrm{F}$ (perbandingan varians terbesar dengan varians terkecil). Setiap kelompok subjek diberi perlakuan sama, kecuali model pembelajaran yang digunakan yaitu kelompok eksperimen menggunakan model pembelajaran kooperatif tipe TAI, sedangkan sedangkan kelompok kontrol menggunakan model konvensional.

\section{HASIL DAN PEMBAHASAN}

\section{Hasil Penelitian}

Hasil deskripsi data pada kelas eksperimen dengan subjek penelitian sebanyak 29 terdapat skor tertinggi adalah 100 dan skor terendah adalah 56 dengan ratarata skor adalah 89.7. Karena rata-rata skor ideal $\left(\mathrm{M}_{\mathrm{i}}\right)$ dan standar deviasi ideal $\left(\mathrm{SD}_{\mathrm{i}}\right)$ masing-masing adalah 50 dan 16,7 maka rata-rata hasil belajar hasil belajar kelas eksperimen lebih tinggi dari rata-rata ideal yaitu $89,7>50$. Selanjutnya hasil belajar siswa pada kelas eksperimen yaitu siswa yang diajar dengan model pembelajaran kooperatif type TAI dikategorikan menjadi empat kategori seperti disajikan dalam tabel 1.

Tabel 1 Kecenderungan Hasil Belajar Kelas Eksperimen

\begin{tabular}{|l|c|c|c|}
\hline Kategori & Interval & $\begin{array}{c}\text { Frekwensi } \\
\text { Absolut }\end{array}$ & $\begin{array}{c}\text { Frekensi } \\
\text { Relatif } \\
(\%)\end{array}$ \\
\hline Tinggi & $\mathrm{x}>75$ & 27 & 93.10 \\
\hline Cukup & $50 \leq \mathrm{x}<75$ & 2 & 6.89 \\
\hline Kurang & $25 \leq \mathrm{x}<50$ & 0 & 0 \\
\hline Rendah & $\mathrm{x}<25$ & 0 & 0 \\
\hline \multicolumn{2}{|c|}{ J u m I a h } & 29 & 100 \\
\hline
\end{tabular}


Pada kelas kontrol dengan subjek penelitian sebanyak 29 terdapat skor tertinggi adalah 100 dan skor terendah adalah 28 dengan rata-rata skor adalah 79,1. Rata-rata hasil belajar hasil belajar kelas kontrol lebih tinggi dari rata-rata ideal yaitu 79,1 > 50 . Kategori hasil belajar kelas kontrol, yaitu siswa yang diajar dengan model pembelajaran konvensional disajikan dalam tabel 2.

Tabel 2 Kecenderungan Hasil Belajar Kelas Kontrol

\begin{tabular}{|l|c|c|c|}
\hline Kategori & Interval & $\begin{array}{c}\text { Frekwensi } \\
\text { Absolut }\end{array}$ & $\begin{array}{c}\text { Frekensi } \\
\text { Relatif } \\
(\%)\end{array}$ \\
\hline Tinggi & $\mathrm{x}>75$ & 22 & 75,86 \\
\hline Cukup & $50 \leq \mathrm{x}<75$ & 4 & 13,79 \\
\hline Kurang & $25 \leq \mathrm{x}<50$ & 3 & 10,34 \\
\hline Rendah & $\mathrm{x}<25$ & 0 & 0 \\
\hline \multicolumn{2}{|c|}{ J u m l a h } & 29 & 100 \\
\hline
\end{tabular}

Hasil uji normalitas data kelas eksperimen dan kelas kontrol dengan menggunakan uji Liliefors disajikan pada tabel 3 yang menunjukkan bahwa data hasil penelitian pada kedua kelas subjek penelitian berdistribusi normal..

Tabel 3. Ringkasan Hasil Uji Normalitas Data Penelitian

\begin{tabular}{|c|c|c|c|c|}
\hline Kelas & $\mathrm{L}_{\text {hitung }}$ & $\alpha$ & $\mathrm{L}_{\text {tabel }}$ & $\begin{array}{c}\text { Kes } \\
\text { impulan }\end{array}$ \\
\hline Eksperimen & 0.160 & \multirow[t]{2}{*}{$5 \%$} & \multirow{2}{*}{$\begin{array}{c}0.16 \\
8\end{array}$} & Normal \\
\hline Kontrol & 0.124 & & & Normal \\
\hline
\end{tabular}

Untuk uji homogenitas varians data digunakan uji perbandingan varians terbesar dengan varians terkecil. Ringkasan hasil uji homogenitas ditunjukkan pada tabel 4 .

Tabel 4. Ringkasan Hasil Uji Homogenitas Data Penelitian

\begin{tabular}{|l|l|l|l|l|l|l|}
\hline Kelas & $\mathbf{n}$ & $\mathbf{S}^{2}$ & $\mathbf{F}_{\mathbf{h}}$ & $\boldsymbol{\alpha}$ & $\mathbf{F}_{\mathbf{t}}$ & $\begin{array}{l}\text { Kes } \\
\text { impulan }\end{array}$ \\
\hline $\mathrm{E}$ & 29 & 100,19 & 1,68 & $\begin{array}{l}5 \\
\%\end{array}$ & 1,87 & Homogen \\
\hline
\end{tabular}

Nilai statistik uji-t dihitung secara manual menghasilkan $\mathbf{t}=11,2$. Harga $\mathbf{t}$ pada tabel dengan $\mathrm{dk}=56$ dan $\alpha=0,05$ adalah 2,003. Dari hasil ini diperoleh bahwa thitung > t-tabel yang berarti bahwa skor rata-rata hasil belajar kelas eksperimen lebih tinggi dari skor kelas kontrol pada taraf signifikansi $95 \%(\alpha=0,05)$. Ini berarti bahwa hipotesis penelitian yaitu "Hasil belajar siswa pada kompetensi dasar mendeskripsikan rangkaian logika dasar yang diajar dengan menggunakan model pembelajaran kooperatif tipe TAI lebih tinggi dari hasil belajar siswa dengan menggunakan model pembelajaran konvensional", dapat diterima.

\section{Pembahasan Penelitian}

Hasil penelitian menunjukkan perbedaan hasil belajar dari kedua kelas subjek penelitian. Rata-rata hasil belajar pada kelas dengan model kooperatif tipe team assisted individualization memiliki rata-rata 89.6 dengan standar deviasi 10.0. Berdasarkan tingkatan kategorinya, diketahui bahwa hasil belajar siswa dengan model pembelajaran TAI cenderung tinggi, yaitu adanya 27 siswa yang berada pada kategori tinggi dan 2 orang lainnya berada pada kategori cukup. Pada kelas kontrol didapat rata-rata 79.0 dengan standar deviasi 16.8 dimana terdapat 22 siswa pada kategori tinggi, 4 siswa pada kategori cukup dan 3 siswa pada kategori kurang.

Perbedaan hasil belajar kelas eksperimen dengan kelas kontrol dapat dilihat pada skor rata-rata kelas eksperimen yang lebih besar dari kelas kontrol. Selain itu, perbedaan hasil belajar dapat dilihat dari kecenderungan hasil belajar yaitu bahwa jumlah siswa dengan kategori tinggi pada kelas eksperimen lebih banyak dari pada kelas kontrol. Hasil ini menunjukkan bahwa hasil belajar siswa yang diajar dengan model pembelajaran kooperatif type TAI lebih tinggi dari yang diajar dengan model konvensional. Perbedaan hasil belajar sebagai pengaruh penggunaan model pembelajaran team assisted individualization yang menuntun siswa untuk bekerja sama dalam kelompoknya masing-masing dimana setiap anggota kelompok diberikan tanggung jawab yang sama dalam keberhasilan kelompoknya. Setiap siswa akan berusaha menyelesaikan masalah dalam kelompoknya. Sedangkan pada model konvensional, siswa menjadi pendengar informasi dari guru dimana guru adalah pusat informasi yang sudah jadi yang mengakibatkan siswa lebih banyak mendengar dan mengingat. 
Hasil pengujian uji-t dengan $\alpha=5 \%$ menyimpulkan bahwa hipotesis diterima. Dengan demikian hasil belajar siswa yang diajar dengan model kooperatif type TAI lebih baik dibandingkan siswa yang diajar dengan model konvensional. Hasil ini menunjukkan bahwa pengaruh penggunaan model pembelajaran kooperatif type TAI memberikan hasil belajar yang lebih baik dibandingkan dengan model pembelajaran konvensional.

\section{KESIMPULAN}

Berdasarkan hasil penelitian disimpulkan bahwa: 1) Hasil belajar mendeskripsikan rangkaian logika dasar siswa yang menggunakan model pembelajaran kooperatif tipe TAI maupun model konvensional cendeung tinggi; 2) Hasil belajar siswa mendeskripsikan rangkaian logika dasar yang menggunakan model pembelajaran TAI lebih tinggi dari siswa dengan model pembelajaran Konvensional; 3) Penggunaan model Pembelajaran Kooperatif tipe Team Assisted Individualization dalam pembelajaran rangkaian logika dasar memberikan pengaruh yang signifikan terhadap hasil belajar siswa.

Beberapa saran terhadap hasil penelitian adalah: 1) proses belajar mengajar sebaiknya menggunakan model pembelajaran kooperatif team assisted individualization, untuk menciptakan suasana yang memampukan siswa lebih mudah menerima pelajaran dengan suasana yang menyenangkan; 2) Para siswa perlu diberi tangggung jawab dan terlibat langsung dalam proses belajar mengajar baik itu di dalam kelas secara keseluruhan maupun dalam kelompok-kelompok yang lebih kecil

\section{DAFTAR PUSTAKA}

Dahar, Ratna Willis. 2011. Teori Belajar dan Pembelajaran. Jakarta : Penerbit Erlangga.
Djamarah

(2016)

Konvensional

Pembelajaran

(https://www.scribd.com/doc/

37765611/Pembelajaran-

Konvensional diakses pada selasa, 12 April 2016)

Huda, Miftahul. 2014. Model-model Pengajaran dan Pembelajaran. Yogyakarta : Pustaka Pelajar.

Isaac, Stephen dan Michael, William B. (1982). Handbook In Research And Evaluation. San Diego: EdITS publishers.

Megocahyo, Anang. 2004. Pembelajaran Konvensional. Diakses pada 12 April 2016 dari https://www.scribd.com/doc/37765 611/Pembelajaran-Konvensional.

Mulyoto. 2013. Strategi Pembelajaran Di Era Kurikulum 2013. Jakarta : Prestasi PustakaKaraya.

Nasution, S. 1982. Berbagai Pendekatan Dalam Proses Belajar Mengajar. Bandung : Bumi Aksara.

Sanjaya, Wina. 2009. Strategi Pembelajaran Berorientasi Standar Proses Pendidikan. Jakarta : Kencana.

Shoimin, Aris. 2014. 68 Model Pembelajaran Inovatif dalam Kurikulum 2013. Yogyakarta : Arruzz Media.

Sudjana. 2001. Metoda Statistika. Bandung : Tarsito.

Sukardi. 2007. Metodologi Penelitian Pendidikan. Yogyakarta : Bumi Aksara. 